\title{
IMPACT OF PERCEIVED BUSINESS RISK ON ORGANIZATION PERFORMANCE: AN INTEGRATED RISK MANAGEMENT FRAMEWORK BASED ON INTERNAL CONTROLS
}

\author{
Dr. Akmal Shahzad* \\ Assistant Professor, Barani Institute of Knowledge Administration and Technology \\ Rawalpindi, Pakistan \\ Dr. Muhammad Khan \\ Assistant Professor, Iqra University, Islamabad, Pakistan \\ Dr. Taseer Salahuddin \\ Assistant Professor, Government Sadiq College Women University, \\ Bahawalpur, Pakistan \\ Sarah Qaim \\ Assistant Professor, Foundation University Islamabad, Pakistan \\ *Corresponding Author
}

\begin{abstract}
The objective of this study is to investigate the mediating role of risk management between the perceived business risk and organization. To examine the proposed model of this study data was collected from the manager having at least 5 years' experience in finance department or risk management department. Stratified sampling technique were used to collect data in this study. Two hundred and four (204) out of three hundred and eighty four (384) distributed questionnaire were received. To analyze the hypothesis, structural equation modeling (SEM) employed in this study to investigate the mediating role of risk management. The results of study reveal that perceived business risk have significant and positive impact on the formalization of risk management, internal controls and organization performance. Further to this, results also found that formal risk management methods and internal controls mediate between the perceived business risk and organization performance. It means that respondent perceived higher organization performance with formalized risk management methods
\end{abstract}


Impact of Perceived Business Risk on Organization Performance: An Integrated Risk Management Framework based on Internal Controls

and strong internal controls against the perceived business risk. This result may be generalized to other listed companies at PSX

Key words: Perceived Business Risk, Formalization of Risk Management, Internal Controls, Risk Management, Business Organization.

Cite this Article: Akmal Shahzad, Muhammad Khan, Taseer Salahuddin and Sarah Qaim, Impact of Perceived Business Risk on Organization Performance: An Integrated Risk Management Framework based on Internal Controls, International Journal of Management, 11(12), 2020, pp 3129-3141.

http://iaeme.com/Home/issue/IJM?Volume=11\&Issue $=12$

\section{INTRODUCTION}

The business environment is dynamic and has become more complex, nifty and ambiguous as a fast revolution in technology and globalization. Hence, the business activity is complex and challenging as compared to the last century (Power, 2013). The uncertainty in financial sector may lead to uncertainty and risk in all activities of business environment (Protiviti, 2006). Therefore, organizations have to identify, cope and control various factors which contribute to risk and uncertainty. As the ability to peceive risk varies from organization to organization depending on risk culture and companies viewpoint towards risk, therefore each organization has different internal controls to balance the risk.

The business environment as anything which can affect the business activity, for instance performance, process and decision (Akpoviroro, 2018). The key components of business environment are political, economical, technological and legal. In dynamic business environment, balancing risk is an efficient approach to handle corporate risk (Berinato, 2004). The efficient risk management (RM) not only reduces the influence of risk on business operations but also generates several beneficial prospects for organizations in uncertainty. In their seminal work, Amit \& Wernerfelt (1990) posit that uncertainty is one of the reasons behind the business risk reduction strategy. A business faces various jeopardies raised from external business environment which may be technological, political and legal (Hoque, 2005; Kannadhasan, Aramvalarthan and Tandon, 2013; Saiful, 2017). In organization prospects, the risk is defined by all the events that affect the performance of company and deviate from the goal. (Hopkin, 2017).

The uncertainty about the existence of risk leads to the concept of perceived risk. Perceived risk belongs to the contextual aspects that risk managers used to develop risk mitigation procedures and controls (Bento, Mertins and White, 2018). Perceived Risk contributes significantly in developing suitable control to cope with similar type of events in the future. Hence, it is very important to realize the risk perception phenomena to develop an understanding among the managers engaged in the finance office as well as RM activities to deal with the business environment volatility (Renn \& Klinke, 2016). The RM comprises of risk identification, risk judgement, preventive measures and risk elimination via available resources. It improves problems solving and decision-making processes. It also reduces costs, compares results, and improves both business continuity and competitive advantage (Fadun, 2013; Graeve et al., 2004). The growing interest in risk management can also be attributed to a number of events such as the collapse of Leman Brothers, American Investment Group (AIG) and many other international Banks in Global Financial Crises (GFC) of 2008. This GFC triggered the need of RM within the organization (Coskun, 2012). Another motive to implement $\mathrm{RM}$ in the organization is to cope with the dynamic changing trend in a business environment. The volatility of a business environment is characterized by the threat from political, economic, and technical resources (Olson and Dash, 2010). Moreover, several other studies have discussed 
the hasty transformation and growing complication in the world conomy (Iansiti, 1995; Hamel, 2001; Chan Kim Renée Mauborgne, Chan Kim and Mauborgne, 2005; Shannassy, 2007; Ghosh, Bhowmick and Kumar Guin, 2014).

The extant literature in the context of risk management provides mixed evidence on organization performance. Some studies empirically examined the risk management and give attention to one particular industries and geographic areas (Callahan \& Soileau, 2017; Cinar et al., 2016; Linciano et al., 2018). Some other studies are devoted to different countries like US, Malaysia, China and Germany (Abdullah et al., 2017; Fraser \& Simkins, 2010; Lechner et al., 2016; Olson \& Dash, 2010a; Pagach \& Warr, 2011; Soltanizadeh et al., 2014). Although there are volumes of research on the given topic, but the application of the research is very limited in case of countries like Pakistan due to differences in regulation and corporate setup, which includes factors like technology, maturity of industries and corporate awareness of the strategic management.

The objective of this study is to investigate the impact of perceived business risk on organization performance in Pakistan as well as the mediatizing role of risk based internal control. Furthermore, it helps to develop awareness regarding RM for both practitioners and academics as it investigates connection between perceived risk and organization performance.

\section{LITERATURE REVIEW AND RESEARCH MODEL}

The term risk defined in many ways, but none of the definitions presents a complete meaning. In literature, risk and uncertainty used interchangeably (Froud, 2003). Therefore, the complexity and rapid change in the world economy in recent years remain the central theme of study among several academics, business executives and consultants (ABCs) (e.g. Rizal \& Mukhammad, 2017; Adeola, 2016; Ogundele, 2005). It was commonly accepted that risk in business operation was the function of business environment. Business risks due to volatility in business environment factors such as financial, technological, political etc. Therefore, an organization must take into account the perceived business risk to develop internal controls to reduce the effect of risk and enhance the organization performance.

The perceived risk refers to the perception of individual about the future events affecting their business decisions. Forlani \& Mullins (2000) had highlighted so many business decisions based on risk perception, e.g. purchasing decisions, financial decisions etc. Perceived business risk focused on organizational risk faced due to uncertain business environment. Risk perception was the important factor in risk mitigation process, which help the managers to forecast risk and its impact on business operations. When the business managers adequately perceive risks, then they use appropriate internal controls to mitigate the risk and to reduce its impact on business operations, which in turn enhance the business performance. To manage the risk is one of the important assignments for top management. "Today organizations are expected to signal the adequacy of their internal management control mechanisms, rather than simply seek to operationalize them. They must promote the view that control exercised in both the taking and the managing of risk. Action to put into effect risk management (RM) is insufficient. Transparency of risk management practices must co-exist with objectified pursuits of risk control." (Bhimani, 2009).

The RM involves the main identification of risk along with appraisal and treatment to counter it using suitable internal controls. This can only be effective if this information shared amongst the organization on a timely basis while having a formalized manner. Formalization of methods satisfy both a control and a coordinated work (Vlaar, Bosch, and Volberda, 2007a). Customarily, formalization seemed as an aspect of authoritative structure and associated to the degree to which an organization depends on rules and standard working methodology to coordinate the conduct of employees (Abdulkadir, 2014; Dawes, Lee, and Midgley, 2007). In 
this study, RM formalization characteristics as the degree to which "RM strategies and procedures are formalized and embraced in a straightforward and precise way". In such conditions, we accept that organizations will endeavor to FRMM as formalization encourages the preparing of material and information that are available to instability in an increasingly methodical and cautious way.

The above literature highlighted the need for firms to develop a sound internal control system that counter the perceived risk and ensures to improve organization performance. Most of the highlighted studies in the literature review do not explicitly address the effect of perceived business risk on the organization in Pakistan. A scarcity of literature in the area of study exists, particularly in developing countries like Pakistan.

In accounting, contingency theory applied to rationalize the superfluity management accounting practice (Otley, 2016). Recently application of contingent theory has extended to describe the RM of organization. All organizations face similar type of risk for instance; market risk, technological risk, operational risk and coopetition risk. Furthermore, increasing the complexity of companies are mergers, deregulation, global competition and general market shifts. Hence, a perceived business risk helps the business leader to manage risks in accordance with its company's characteristics, being size and nature of the operations, in order to realize the company's objectives. Despite the fact that risks can take various forms, each risk should not be managed separately and a segment view of risk should be avoided (Jankensgård, 2019). The organization's environment is a fundamental factor that shapes the internal managerial structure and internal controls systems, which are vital to encounter risks and uncertain events (Burns and Stalker, 1961; Lawrence and Lorsch., 1967; Akuro, 2019).

In their seminal work, Songling, Ishtiaq, \& Anwar (2018) established that the organization performance and risk management are positively and significantly associated with each other. On the other hand Subramaniam, Collier, Phang, \& Burke (2011) suggested the noteworthy association between formalized RM and organization performance. Most importantly, both variables create positive impact on the organizational outcomes.

Therefore, the formalization aspect is central to this study and a formalization of risk refers to the standards of behaviors, specific norms and shared values. This is often viewed as a costeffective solution that enables efficiency by making polices formal to be followed and work standards. In most organizations, the formalization element is incorporated to eliminate ambiguity and to follow instructed work structures with minimum cost involved. Talja (2016) analyzes the relationship between the management formalization and the company's operations and concludes the need for formalizing the processes for global and internal transparency. The magnitude of risk management methods emphasizes the need to have a constructive measure in order to promote transparency and reduce ambiguity.

In the aforementioned literature, the proposed framework becomes very apparent. The initial step is to recognize the risk; the nature of risk may be altered by the nature of business (large, small, manufacturing, and services, Islamic or conventional). The recognition of risk has led the management to set up a system of internal controls; this blend of internal control reduced the risk of the organization with its two arms. The first is risk management formalization and the second is the magnitude of risk management methods. Once both arms of the system are efficient, the risk of the business is controlled or reduced, and the performance is optimized. It is obvious from the pictorial representation of theoretical framework in Figure 2.1. The proposed model, based upon the literature review, presents the relationship between the perceived business risk, internal controls, formalization of RM, and organization performance.

H1: PBR has a positive and significant impact on Organization performance

$\mathrm{H} 2$ : PBR has a positive and significant impact on FRMM 
H3: PBR has a positive and significant impact on Internal Controls

H4: Internal Controls have a positive and significant impact on Organization Performance

H5: FRMM has a positive and significant impact on Organization performance

H6: PBR has a positive and significant impact on Organization performance mediating by Internal Controls

H7: PBR has a positive and significant impact on Organization performance mediating by FRMM

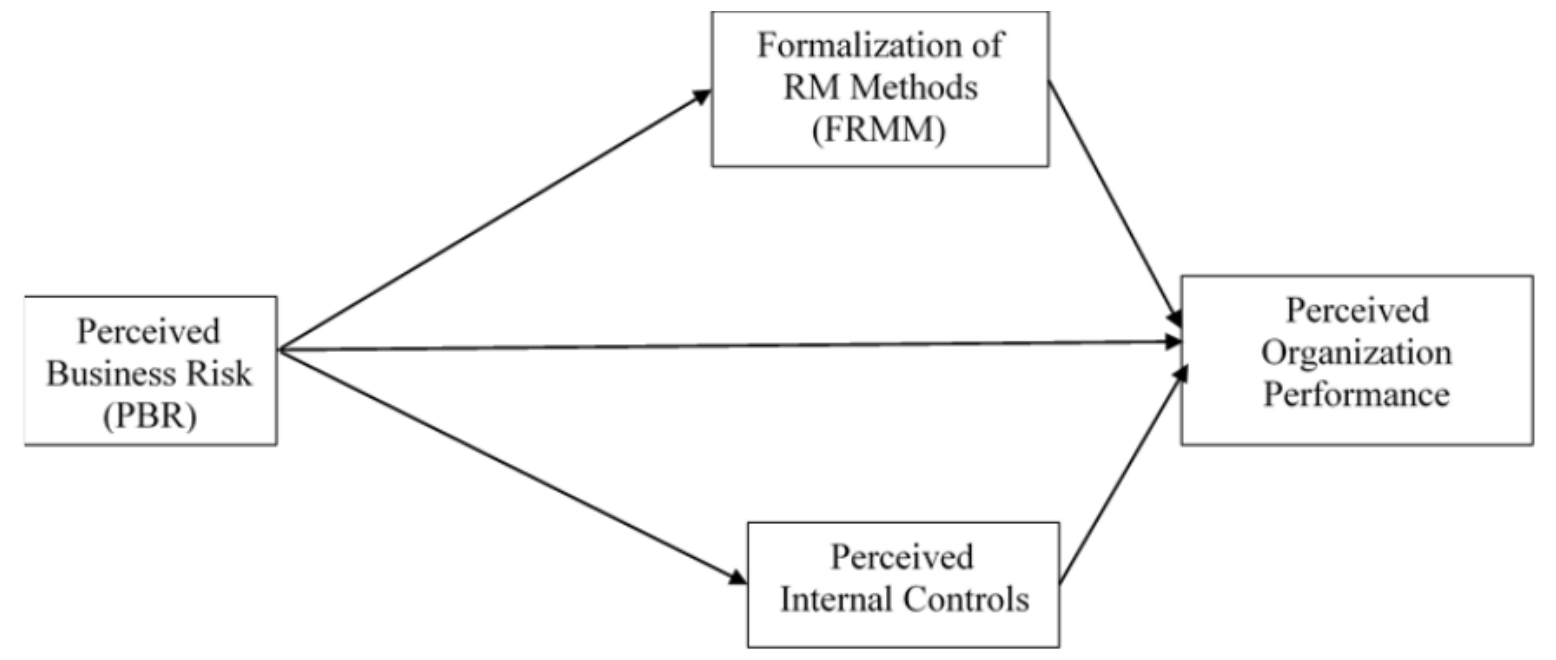

Figure 1 Theoretical ModelHypothesis Statements

\section{RESEARCH METHOD}

\subsection{Populatin and Sample}

The population of the current study is includes the chief financial manager, the chief risk officers, member of RM committee, and all those risk managers having minimum experience of five years in risk department or finance department. There are five hundred and seventy five publicly listed companies as per the list obtained from the Pakistan Stock Exchange and hence these companies define our population. Stratified sampling technique were used to collect data in this study. Structural equation modeling (SEM) employed in this study to investigate the mediating role of risk management.

\subsection{Measurement}

In designing the questionnaire, we collected and consulted the existing and relevant literature (Ho\& Pike, 1998; Cohen, 2001). This study has used four variables namely; perceived business risk, formalization of RM methods, internal controls and perceived company performance. Responses to the questionnaire items were measured on a five-point scale. The detail of instrument of the study variables adapted from the literature is given in table 1 below.

Table 1 Number of items and source of each variable

\begin{tabular}{|c|c|c|c|}
\hline Sr. No. & Variables & Items & Sources of Questionnaire \\
\hline 1 & Perceived Business Risk & 25 & $\begin{array}{c}\text { (Jusoh, 2010; Miles, Snow, Meyer, \& Coleman, 1978; } \\
\text { Miller, 1993; Piskunov et al., 2016) }\end{array}$ \\
\hline 2 & Internal Controls & 27 & $\begin{array}{c}\text { (Chow et al., 2005; Ayagre, Appiah-Gyamerah and } \\
\text { Nartey, 2014; Kang and Kinyua, 2016; Eke, 2018) }\end{array}$ \\
\hline 3 & Formalization of Risk Management & 15 & (Miles et al., 1978; Subramaniam et al., 2011) \\
\hline 4 & Organization Performance & 14 & (Govindarajan and Gupta, 1985; Jusoh, 2008, 2010) \\
\hline
\end{tabular}

Source: Own elaboration 


\subsection{Statistical Analysis Techniques}

Porior to use questionnaire for data collection, its reliability and validity measured by using cronbach alpha and CFA respectively. The following statistical measure to examine the reliability and validity of the instrument items. The measures incorporated into the study have the substance, prescient, convergent and discriminant validity. The substance validity is inspected through pilot study including senior finance professionals. The convergent validity of each develop, demonstrated in the intelligent mode, is checked by inspecting the "average variance extracted (AVE)" values. AVE qualities are more noteworthy than the base threshold level for instance 0.50 (Hair et al, 2006) or was close enough to 0.50 to be satisfactory (Cohen 2001). All develops had surpassed the base AVE esteem or were close enough to the satisfactory level, see table 3 underneath. The discriminant validity can be done by looking at the square foundation of a build's AVE, which ought to be more prominent than the connection between one develop and different builds utilized in the model or squared relationship between the develops which ought to be not exactly the AVE (see Fornell Larcker, 1981, Hair et al 2006). The AVE esteems are more prominent than the R-square esteem (0.472), which shows that every one of the builds have great discriminant validity see table 2 .

Table 2 Validity Test

\begin{tabular}{|c|c|c|c|}
\hline Test & Acceptance Level & Result of Study & Decisions \\
\hline Factor Load & $>0.60$ & All factor load $>0.60$ & $\begin{array}{c}\text { All item were deleted below } \\
\text { criteria }\end{array}$ \\
\hline Reliability & $>0.60$ & All construct $>0.90$ & Reliable \\
\hline Convergent Validity & $>0.50$ & All construct $>0.50$ & Sonsistent \\
\hline Discriminant Validity & SIC $<$ AVE & $\begin{array}{c}\text { All construct met the } \\
\text { criteria }\end{array}$ & Supported \\
\hline Nomological Validity & $\begin{array}{c}\text { Relationship support } \\
\text { the theoretical }\end{array}$ & $\begin{array}{c}\text { All relationship as per } \\
\text { theoretical }\end{array}$ & Puported \\
\hline
\end{tabular}

\subsection{Results}

In order to test the adaptability of the model, structural model was performed in AMOS. Values for all model fitness indicators fall above the criteria indicate the best choice for our model at suggested levels see table 3

Table 3 Model Fits

\begin{tabular}{|c|c|c|}
\hline $\begin{array}{c}\text { Model Fit } \\
\text { Criteria }\end{array}$ & Measurement Model & Acceptable Range* $^{*}$ \\
\hline$\chi^{2}$ & 1.20 & - \\
\hline $\mathrm{df}$ & 1 & - \\
\hline$\chi^{2} / d f$ & 1.39 & $1-3$ \\
\hline GFI & 0.99 & $>0.90$ \\
\hline AGFI & 0.96 & $>0.80$ \\
\hline CFI & 0.99 & $>0.95$ \\
\hline TLI & 0.98 & $>0.90$ \\
\hline NFI & 0.99 & $>0.90$ \\
\hline RMR & 0.01 & $<0.09$ \\
\hline RMSEA & 0.04 & $<0.08$ \\
\hline PCLOSE & 0.35 & $>0.05$ \\
\hline
\end{tabular}

Notes: *There is no universal criterion for model fitness. This study relied on $\mathrm{Hu}$ and Bentler (1999) and Hair et al. (2010) 
After determining the model fit, the next step is the estimation of the model through regression coefficients. Present study used the procedure of Hayes \& Preacher (2014) to check the relationship among independent variables and dependent variable. Structural equation modeling (SEM) technique employed for this purpose.

\subsection{Hypothesis Testing}

After validating the model, next step was to scrutinize the hypotheses formulated after extensive literature review. The first hypothesis describes the association between perceived business risk and perceived organization performance $\left(\mathrm{H}_{1}\right)$. From the results in table 4 , it is depicted that the effect of perceived business risk on organization performance is significant and positive $(\beta 1=$ $0.18, \mathrm{p}<0.05)$. Hence, the result supports the suggested relationship between both variables i.e. there is significant and positive association among perceived business risk and organization performance thus confirming H1. Additionally, the CR (i.e. 2.258) value is also exceeding the critical value i.e. 1.96, which confirmed the significant and positive influence.

For the hypothesis H-2 which examined the association among perceived business risk and formalization of RM methods, the statistics illuminated the positive association between perceived business risk and formalization of RM methods with significant path coefficient $(\beta 2=$ $0.15, \mathrm{p}<0.05)$ confirming the implication that perceived business risk and formalization of RM methods associate with each other significantly and positively. Hence, the results support the argument H2. Additionally, the CR (i.e. 2.542) value is also exceeding the critical value i.e. 1.96, which confirmed the significant and positive influence.

The third hypothesis (H3) examined the link between perceived business risk and perceived internal controls. The results revealed that the path coefficient $(\beta 3=0.13, p<0.05)$ significantly and positively affect the perceived business risk on perceived internal controls in the organization. Therefore, this study supported the argument that perceived business risk and perceived internal controls is significant and positively associated. Additionally, the CR (i.e. 2.258) value is also exceeding the critical value (i.e. 1.96) which confirmed the significant and positive influence.

The argument of hypothesis $\mathrm{H}-4$, which presents that the highly formalized RM methods enhance the organization performance, has examined. The path coefficient $(\beta=0.28, p<0.05)$ revealed the significant and positive effect of formalization of RM methods on organization performance. Hence, the results of this study supported the H-4 argument about the direct relation and positive and significant association between formalization of RM methods and organization performance. Hence, H-4 is acceptable. Additionally, the CR (i.e. 5.048) value is also exceeding the critical value (i.e. 1.96) which confirmed the significant and positive influence.

The path coefficient $(\beta=0.32, p<0.05)$ in $\mathrm{H}-5$ explained that internal controls affect organizational performance directly, positively and significantly. This finding supported the $\mathrm{H}-$ 5 argument that the internal controls leads to improve organization performance. Hence, the $\mathrm{H}-$ 5 of the study is also accepted. Additionally, the CR (i.e. 6.198) value is also exceeding the critical value (i.e. 1.96), which confirmed the significant and positive influential contribution.

The brief results for the above-discussed hypotheses presented in Table 4. The results revealed that $C R$ value for all the arguments were more than the critical value i.e. 1.96 for 5\% level of significance. This implies that all the arguments of this study were accepted. 
Impact of Perceived Business Risk on Organization Performance: An Integrated Risk Management Framework based on Internal Controls

Table 4 Summary of Findings $\left(\mathrm{H} 1-\mathrm{H}_{5}\right)$

\begin{tabular}{|c|c|c|c|c|c|c|c|}
\hline & & & $\begin{array}{l}\text { Regression Weight } \\
\text { (Standardized) }\end{array}$ & $\mathbf{S E}$ & CR & p-Value & Remarks \\
\hline PBR & $\longrightarrow$ & PER & 0.18 & 0.059 & 3.533 & $* * *$ & Supported \\
\hline PBR & $\rightarrow$ & FRMM & 0.15 & 0.055 & 2.542 & 0.011 & Supported \\
\hline PBR & $\longrightarrow$ & IC & 0.13 & 0.059 & 2.258 & 0.024 & Supported \\
\hline FRMM & 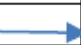 & PER & 0.28 & 0.050 & 5.482 & $* * *$ & Supported \\
\hline IC & 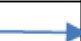 & PER & 0.32 & 0.047 & 6.198 & *** & Supported \\
\hline
\end{tabular}

\subsection{Testing Mediation Hypotheses H6-H7}

The research model of this study presented in section 2.3, proposed the RM structured on internal control (i.e. formalization of RM methods and internal controls) as a mediator between perceived business risk and organization performance. We completes this analysis in two steps. In the first step, we check the impact of perceived business risk on mediating variables that is to say the internal control and formalization of RM methods. In the second step, we investigate the association of both mediating variables with dependent variables that is organization performance. Here Baron and Kenny (1986) specified the prerequisite conditions for a mediating variable in model.

Table 5 Summary of Hypotheses results H6 \& H7

\begin{tabular}{|c|c|c|c|c|c|c|c|}
\hline \multirow{2}{*}{\multicolumn{2}{|c|}{ Path }} & \multirow{3}{*}{$\begin{array}{l}\text { Mediating } \\
\text { Variable } \\
\text { Internal Controls }\end{array}$} & \multicolumn{2}{|l|}{ Direct Path } & \multicolumn{2}{|c|}{ Indirect Coefficient } & \multirow{3}{*}{$\begin{array}{l}\text { Remarks } \\
\text { Partial } \\
\text { Mediation }\end{array}$} \\
\hline & & & Coefficient & Sig. & Coefficient & Sig. & \\
\hline PBR - & PER & & 0.18 & 0.059 & 0.078 & 0.025 & \\
\hline PBR & PER & $\begin{array}{l}\text { Formalization of } \\
\text { Rm Method }\end{array}$ & 0.18 & 0.059 & 0.038 & 0.001 & $\begin{array}{l}\text { Partial } \\
\text { Mediation }\end{array}$ \\
\hline
\end{tabular}

The result presented in table 5 depicted that the regression weights have reduced from 0.18 to 0.078 in case of internal controls used as mediating variable. The relationship path between perceived business risk and organization performance remain positive and significant, which indicate partial mediation among dependent and independent variables. Hence accepted the hypothesis H6. Similarly, the regression weights have reduced from 0.18 to 0.038 when formalization of RM method used as mediating variable. The relationship path between perceived business risk and organization performance remain positive and significant, which indicate partial mediation among dependent and independent variables. Hence accepted the hypothesis $\mathrm{H} 7$.

\section{DISCUSSION}

The main purpose of present study is to investigate the role of internal controls-based RM model in order to improve organizational performance in an uncertain business environment. The findings confirm that the identification and implementation of rigorous internal controls systems are an essential part of RM, as effective internal controls would not only help management to limit the probability of the risk occurrence but also enable the organization to take advantage of risk, thus converting risk into an opportunity. As managers across the industries in Pakistan hold internal controls as one the most important aspects of RM framework, but at same time, the mangers in financial sectors tend to give more importance to this aspect as compared to the non-financial sector. Our findings are in line with those of Vasile \& Croitoru, 2016.

On a similar note, the formalization of the RM method is also considered significantly important in business operations to reduce the risk and enhance financial performance. Our 
findings conclude that the formalized RM practices ar the most important part of the business. The financial sector has a more formalized structure than the non-financial sector.

It is a commonly accepted fact that business risk is one of the most important determinant of an organization's internal control, which in turn is an integral part of the RM frame. The current findings depicted that financial sector management is more conscious about the uncertain business environment to avoid any sort of business risk therefore tend to give more importance to it. These findings are consistent with the findings of (Kundu and Bhattacharya, 2017).

The present study finds that perceived business risk has a direct impact on the organization performance on financial performance as supported by earlier studies (Haque and Ali, 2016). Similarly, studies focusing on the impact of perceived business risk on internal controls are supported by (Vasile and Croitoru, 2016), formalization of RM methods is supported by (Baum and Wally, 2003). The investigation reveals that a significant relationship between organization performance and internal controls supported by the findings of (Kamau, 2014), between internal control and formalization of RM is supported by (Talja, 2016).

The study further finds the significant mediating effects of internal control and formalization of RM methods on the overall financial performance of the company. According to the analysis, perceived business risk has a positive impact on internal control, which in turn has a progressive impact on organizational performance as held earlier by (Tseng, 2007). Therefore, results revealed that perceived business risk has a significant impact on the financial performance fully mediated by internal controls as per findings held by Hayes (2013). Similarly, with the formalization of RM methods used as a mediator between perceived business risk and organization's performance. The results revealed that all the variables has considered as partial mediation variables and they have a positive effect on the organization performance.

\section{CONCLUSION AND RECOMMENDATION}

With the change in technology and fast-evolving trends in globalization, organizations operating in developing countries are facing challenges relating to their survival. Governments following global trade liberalization regimes take down the barriers to entry in markets such as Pakistan. This has led to increased volatility in the general business environment, leading to an increase in volatility and general risk level. Pakistan has remained vulnerable to domestic and external challenges since its birth. These challenges were heightened by the unstable political conditions, the prevalence of natural disasters, and socio-economic changes within the society. The interplay of all these factors created volatility in the overall economic environment. The factors have created a negative perception concerning the organizational performance.

This study aims at investigating the impact of perceived business risk on organizational performance and the mediating role of risk management (RM) base on intermural control. The findings of this study indicated that perceived business risk has a positive impact on internal control, the formalization of RM methods, and organization performance. Whereas internal control has a strong and positive association with the formalization of RM methods, and performance of an organization. The current study also found a positive relationship between formalization of RM methods and organization performance. Furthermore, this study also found the mediating effect of internal control and formalization of RM methods.

The findings of this study posit that perceived business risk assumes a significant job in accomplishing high organizational performance being influenced by perceived business uncertainty, which in turn influences organizational performance. It could be argued that perceived business risk influences organizational performance through internal controls and formalization of RM methods. Hence, to achieve higher organizational performance managers should consider business uncertainty, 
internal controls and formalized of RM methods that are consistent with regulatory body guidelines and help to enhance performance.

Organizations unavoidably need to experience the auxiliary, procedural and administrative changes. It is significant for managers to comprehend the risk recognition and internal control relationship in two different ways because both greatly affect organizational execution and they cannot be isolated from one another since vulnerability in business condition impacts the level of internal control and the other way around. As it is obvious that improvement in the internal control system reduces the risk perception within and outside the organization, which leads to better financial performance, but at the same time, these organizations can only achieve this by formalizing the risk management procedures. The implementation of the internal control to the corporate financial strategy can have both positive and negative consequences, also for the level of the company's risk. This study can provide a guide for managers to achieve higher organizational performance.

\section{REFERENCES}

[1] Akpoviroro, K. S. (2018) 'Impact of External Business Environment on Organizational Performance', IJARIIE-ISSN(O)-2395-4396, 4(3), pp. 498-505. doi: 10.1016/09255273(92)90020-8.

[2] Akuro, P. (2019) 'Social Internal Control Mechanisms and Revenue Generation in Rivers State Internal Revenue Service (RIRS)', Arts and Social Sciences Journal, 10(1), pp. 1-8. doi: 10.4172/2151-6200.1000431.

[3] Amit, R. and Wernerfelt, B. (1990) 'Why Do Firms Reduce Business Risk?', Academy of Management Journal, 33(3), pp. 520-533. doi: 10.5465/256579.

[4] Ayagre, P., Appiah-Gyamerah, I. and Nartey, J. (2014) 'The Effectiveness of Internal Control Systems of Banks. The Case of Ghanaian Banks', International Journal of Accounting and Financial Reporting, 4(2), p. 377. doi: 10.5296/ijafr.v4i2.6432.

[5] Baum, J. R. and Wally, S. (2003) 'Strategic decision speed and firm performance', Strategic Management Journal, 24(11), pp. 1107-1129. doi: 10.1002/smj.343.

[6] Bento, R. F., Mertins, L. and White, L. F. (2018) 'Risk management and internal control: A study of management accounting practice', in Advances in Management Accounting. Emerald Group Publishing Ltd., pp. 1-25. doi: 10.1108/S1474-787120180000030002.

[7] Berinato, S. (2004) 'Risk's Rewards'. Available at:

https://www.cio.com.au/article/181713/risk_rewards/?pp=5 (Accessed: 10 September 2017).

[8] Burns, T. and Stalker, G. M. (1961) The Management of Innovation. Tavistock, London.

[9] Callahan, C. and Soileau, J. (2017) 'Does Enterprise risk management enhance operating performance?', Advances in Accounting, 37, pp. 122-139. doi: 10.1016/j.adiac.2017.01.001.

[10] Chan Kim Renée Mauborgne, W., Chan Kim, W. and Mauborgne, R. (2005) Blue Ocean Strategy: from Theory to Practice adapted from Blue Ocean Strategy: How to Create Uncontested Market Space and Make the Competition Irrelevant by, California Management Review.

[11] Chow, E. K. F. et al. (2005) 'Internal control and risk management: A basic framework'. Available at:

http://app1.hkicpa.org.hk/corporate_relations/media/pressrelease/2005/ICRM_Guide_final.pdf 
[12] Cinar, G., Isin, F. and Hushmat, A. (2016) 'Classification of Risk Perceptions of Trading Firms', Journal of Financial Risk Management, 05(01), pp. 7-13. doi: 10.4236/jfrm.2016.51002.

[13] Coskun, Y. (2012) 'Financial Failures and Risk Management'.

[14] Eke, G. O. (2018) 'Internal Control and Financial Performance of Hospitality Organizations in Rivers State', 6(3), pp. 32-52.

[15] Fadun, O. S. (2013) 'Insurance, A Risk Transfer Mechanism: An Examination Of The Nigerian Banking Industry', IOSR Journal of Business and Management, 7(4), pp. 93-101. doi: $10.9790 / 487 x-07493101$.

[16] Ghosh, S., Bhowmick, B. and Kumar Guin, K. (2014) 'Perceived Environmental Uncertainty for Startups: A Note on Entrepreneurship Research from an Indian Perspective', Technology Innovation Management Review, 4(8), pp. 27-35. doi: 10.22215/timreview820.

[17] Govindarajan, V. and Gupta, A. K. (1985) 'Linking control systems to business unit strategy: impact on performance', Accounting, Organizations and Society, 10(1), pp. 51-66. doi: 10.1016/0361-3682(85)90031-5.

[18] Graeve, F. De, Jonghe, O. De and Vennet, R. Vander (2004) 'Competition, transmission and bank pricing policies: Evidence from Belgian loan and deposit markets', Working Papers of Faculty of Economics and Business Administration, Ghent University, Belgium.

[19] Hamel, G. (2001) 'Leading the revolution': Strategy \& Leadership, 29(1), pp. 4-10. doi: $10.1108 / 10878570110367141$.

[20] Haque, M. and Ali, I. (2016) 'Uncertain environment and organizational performance: The mediating role of organizational innovation', Asian Social Science, 12(9), pp. 124-138. doi: $10.5539 /$ ass. v12n9p124.

[21] Hopkin, P. (2017) Fundamentals of Risk Management: Understanding, Evlauating and Implementing Effective risk Management. 4th edn, The British Journal of Psychiatry. 4th edn. London: Kogan Page Limited. doi: 10.1192/bjp.112.483.211-a.

[22] Hoque, Z. (2005) 'Linking environmental uncertainty to non-financial performance measures and performance: A research note', British Accounting Review, 37(4), pp. 471-481. doi: 10.1016/j.bar.2005.08.003.

[23] Hoyt, R. E. and Liebenberg, A. P. (2011) 'The Value of Enterprise Risk Management', Journal of Risk and Insurance, 78(4), pp. 795-822. doi: 10.1111/j.1539-6975.2011.01413.x.

[24] Iansiti, M. (1995) 'Shooting the Rapids: Managing Product Development in Turbulent Environments’, California Management Review, 38(1), pp. 37-58. doi: 10.2307/41165820.

[25] Jankensgård, H. (2019) 'A theory of enterprise risk management', Corporate Governance (Bingley), 19(3), pp. 565-579. doi: 10.1108/CG-02-2018-0092.

[26] Jusoh, R. (2008) 'Environmental Uncertainty, Performance, and the Mediating Role of Balanced Scorecard Measures Use: Evidence from Malaysia', International Review of Business Research Papers, 4(2), pp. 116-135.

[27] Jusoh, R. (2010) 'The influence of perceived environmental uncertainty, firm size, and strategy on multiple performance measures usage', African Journal of Business Management, 4(10), pp. 1972-1984. 
Impact of Perceived Business Risk on Organization Performance: An Integrated Risk

Management Framework based on Internal Controls

[28] Kamau, C. N. (2014) 'Effect of Internal Controls on the Financial Performance of Manufacturing Firms in Kenya By a Research Project Submitted in Partial Fulfillment of the Requirement for the Award of the Degree of Master of Science in Finance, University of Nairobi', Deparment of Finance and Accounting, School of Business, University of Nairobi ii.

[29] Kang, J. and Kinyua, A. R. U. (2016) 'Effect of Internal Control System on financial performance of Companies Quoted in the Nairobi Security Exchange', International Journal of Business \& Law Research, 3(4), pp. 1-212.

[30] Kannadhasan, M., Aramvalarthan, S. and Tandon, D. (2013) 'Perceived Environmental Uncertainty \& Company Performance: An Effect on Strategic Investment Decisions', International Journal of Accounting and Financial Management Research (IJAFMR), 3(4), pp. $107-118$. Available http://www.tjprc.org/view_archives.php?year=2013\&id=35\&jtype=2\&page=3 .

[31] Kundu, A. and Bhattacharya, A. (2017) 'Dimensions of Uncertainty and its Impact on Performance Amit', Great Lakes Herald, 11(1), pp. 60-76.

[32] Lawrence, P. R. and Lorsch., J. W. (1967) Organization and Environment. Boston, MA: Harvard Business School, Division of Research.

[33] Linciano, N. et al. (2018) 'How financial information disclosure affects risk perception. Evidence from Italian investors' behaviour', European Journal of Finance, 24(15), pp. 13111332. doi: 10.1080/1351847X.2017.1414069.

[34] Miles, R. E. et al. (1978) 'Organizational strategy, structure, and process.', Academy of management review. Academy of Management, 3(3), pp. 546-562. doi: 10.5465/AMR.1978.4305755.

[35] Miller, K. D. (1993) 'Industry and Country Effects on Managers' Perceptions of Environmental Uncertainties Author ( s ): Kent D . Miller Published by: Palgrave Macmillan Journals Stable URL: http://www.jstor.org/stable/155171 Accessed: 21-05-2016 17: 01 UTC', Journal of International Business Studies, 24(4), pp. 693-714.

[36] Ogundele, O. J. (2005) Management and Organization: Theory and Behaviour. Molofin Nominees, Lagos.

[37] Olson, D. L. and Dash, D. (2010) 'A review of enterprise risk management in supply chain', Kybernetes, pp. 694-706. doi: 10.1108/03684921011043198.

[38] Otley, D. (2016) 'The contingency theory of management accounting and control: 1980-2014', Management Accounting Research, 31, pp. 45-62. doi: 10.1016/j.mar.2016.02.001.

[39] Pagach, D. P. and Warr, R. S. (2011) 'The Effects of Enterprise Risk Management on Firm Performance', SSRN Electronic Journal. doi: 10.2139/ssrn.1155218.

[40] Piskunov, V. A. et al. (2016) 'Risk-oriented internal control: The essence, management methods at small enterprises', Mathematics Education, 11(7), pp. 2710-2731.

[41] Power, M. (2013) 'The apparatus of fraud risk', Accounting, Organizations and Society, 38(67), pp. 525-543. doi: 10.1016/j.aos.2012.07.004.

[42] Protiviti (2006) Guide to Enterprise Risk Management Frequently Asked Questions, Acta Physiologica Scandinavica. doi: 10.1111/j.1748-1716.1970.tb04819.x. 
[43] Renn, O. and Klinke, A. (2016) Risk Perception and Its Impacts on Risk Governance. doi: 10.1093/acrefore/9780199389414.013.2.

[44] Ricardo, K. et al. (2015) 'Agribusiness gross domestic product (GDP) in the Brazilian region of paran and, the economic development of its agricultural cooperatives', African Journal of Agricultural Research, 10(48), pp. 4384-4394. doi: 10.5897/ajar2015.10208.

[45] Saiful, S. (2017) 'Contingency Factors, Risk Management, and Performance of Indonesian Banks', Asian Journal of Finance \& Accounting, 9(1), p. 35. doi: 10.5296/ajfa. v9i1.10372.

[46] Shannassy, T. O. (2007) 'Perceived Environmental Uncertainty and Organization Performance', Perceived Environmental Uncertainty and Organization Performance, pp. 1-19.

[47] Songling, Y., Ishtiaq, M. and Anwar, M. (2018) 'Enterprise Risk Management Practices and Firm Performance, the Mediating Role of Competitive Advantage and the Moderating Role of Financial Literacy', Journal of Risk and Financial Management, 11(3), p. 35. doi: $10.3390 / \mathrm{jrfm} 11030035$.

[48] Subramaniam, N. et al. (2011) 'The effects of perceived business uncertainty, external consultants and risk management on organisational outcomes', Journal of Accounting and Organizational Change, 7(2), pp. 132-157. doi: 10.1108/18325911111139671.

[49] Talja, S. (2016) Formalization of Management Control System in Venture Capitalist context. University of Tampere.

[50] Tseng, C.-Y. (2007) Internal Control, Enterprise Risk Management, and Firm Performance.

[51] Vasile, E. and Croitoru, I. (2016) 'Integrated Risk Management System - Key Factor of the Management System of the Organization', in. IntechOpen. doi: http://dx.doi.org/10.5772/47883.

[52] Williams, Michael, S. and Peter, C. Y. (1998) Risk management and insurance / C. Arthur Williams, Jr., Michael L. Smith, Peter C. Young. - Version details - Trove. Available at: https://trove.nla.gov.au/work/9720526?q\&sort=holdings+desc\&_=1566884859533\&versionId $=46256920$. 